\title{
An Extra Small Metacentric Chromosome in a Female Child
}

\author{
ROBERT F. TAMBURRO and CHARLES E. JOHNSON
}

From the Youngstown Hospital Association, Department of Laboratories, Youngstown, Ohio, U.S.A.

Three cases associating multiple congenital anomalies with a small extra metacentric chromosome have been reported by Frøland, Holst, and Terelev (1963), Gustavson, Atkins, and Patricks (1964), and Taft, Dodge, and Atkins (1965). All three occurred in boys. Because this occurred in male patients only, the possibility that this extra small chromosome was associated with the $\mathrm{X}$ chromosome could not be disproved. In this report, we wish to record the presence of a similar chromosomal abnormality occurring in a mentally retarded female child.

\section{Case Report}

Clinical Aspects. The patient, a newborn white female, was delivered at 38 weeks' gestation by caesarean section because of placenta praevia. The mother, a 36-year-old white woman gravida IV, para III, had an unremarkable prenatal course until the 38th week of gestation, when vaginal spotting was noted. A diagnosis of placenta praevia was made, and a caesarean section was done. At birth, the infant's general condition was good. A few hours after birth there was mild peri-oral cyanosis which cleared spontaneously after 24 hours. The infant's weight at birth was $6 \mathrm{lb}$. I oz. $(2749$ g.). The only abnormalities noted were low-set protruding ears and a left pre-auricular sinus. There was a question of mild right facial weakness. Three days after birth the patient was noted to be excessively irritable and hypertonic; she was discharged on the Ioth hospital day. Following discharge the patient's somatic growth was normal, but mental development was distinctly retarded. At 2 years of age, she was admitted to the hospital for correction of a left convergent strabismus. Resection of the left internal rectus and left rectus external muscles was performed and the patient tolerated the procedure well.

She was seen by us at age 2 years and 10 months because of mental deficiency. At this time her height was 37 in. $(94 \mathrm{~cm}$.) (50th percentile) and her weight was $29 \mathrm{lb}$. (13.2 kg.) (25th percentile). A right convergent strabismus was present. A distinct right facial weakness was noted. The pupils were round, regular, and equal,

Received January 5, 1966. and reacted to light. The child was quite irritable throughout the examination and the fundi could not be examined. The ears were small and low set, and the right ear protruded. A small left pre-auricular sinus was present. The auditory canals were normal. The throat was normal. There was no high arching of the palate. There was some resistance to flexion of the neck. The heart rhythm was regular and no murmurs were audible. The lungs were clear to auscultation and percussion. The abdomen was soft and not tender. No abnormal masses were palpable. The external genitalia, and the extremities, which were normal, resisted passive flexion but were not completely spastic. The deep tendon knee reflexes bilaterally were 4-plus with clonus. There was abduction spasm of the lower extremities. Plantar reflexes were flexor. Biceps and triceps reflexes were 3-plus. The child's gait was wide based, flat footed, and stiff legged. No palmar crease was present. The vocabulary was limited to a few guttural sounds.

TABLE I

CHROMOSOME COUNTS

\begin{tabular}{l|r|r|r|r|r|c}
\hline & 44 & 45 & 46 & 47 & Total & Analysed \\
\hline Blood I & I & I & 8 & 90 & 100 & 20 \\
Blood II & 0 & 0 & 5 & 50 & 55 & 10 \\
\hline Total & I & I & I3 & 140 & I55 & 30 \\
\hline
\end{tabular}

Chromosome Studies. Cells from the buccal mucosa were positive for sex chromatin. Chromosome studies (Fig. I) were carried out on the peripheral blood by modification of the method of Moorhead, Nowell, Mellman, Battips, and Hungerford (1960). The studies revealed a modal number of 47 (Table I). The extra chromosome was a very small metacentric and, as in the other cases reported, this chromosome was also smaller than 21-22 and Y (Fig. 2). Karyotype analysis of the mother and father disclosed no abnormalities.

\section{Discussion}

As seen in Table II, the only consistent clinical findings in all four cases were mental retardation, 


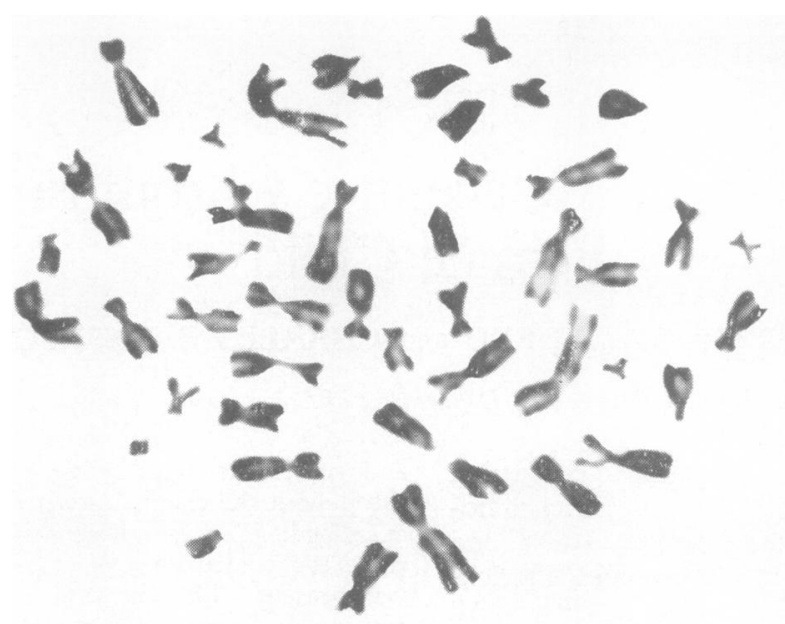

generalized muscular hypertonicity, and small low-set ears. Other clinical abnormalities varied considerably, and no clear-cut clinical syndrome can as yet be established. Since this patient is both genotypically and phenotypically a female, it is apparent that the presence of this small extra metacentric chromosome is not limited to males. Although we cannot exclude definitely the possi-

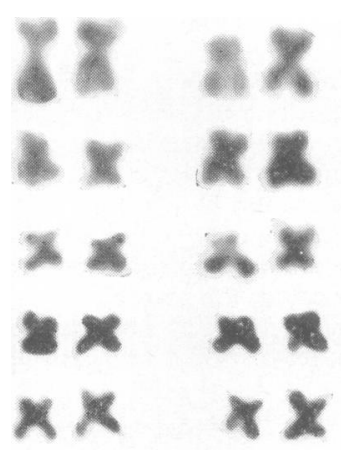

19

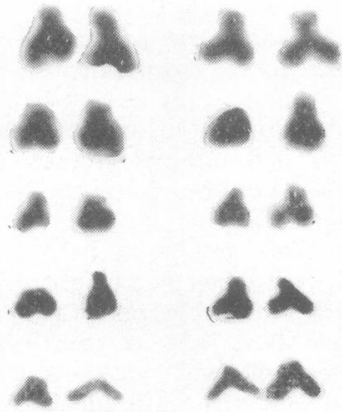

21
22

FIG. 2. F and G group chromosomes and the small extra metacentric chromosome in five cells. 
TABLE II

CLINICAL FINDINGS OF CASES

\begin{tabular}{|c|c|c|c|c|}
\hline & $\begin{array}{l}\text { Frøland } \\
\text { et al. (1963) }\end{array}$ & $\begin{array}{l}\text { Gustavson } \\
\text { et al. (1964) }\end{array}$ & $\begin{array}{c}\text { Taft } \\
\text { et al. (I965) }\end{array}$ & $\begin{array}{c}\text { Present } \\
\text { Case (1966) }\end{array}$ \\
\hline $\begin{array}{l}\text { Sex } \\
\text { Age (yr.) } \\
\text { Small head } \\
\text { Eyes } \\
\text { Epicanthal folds } \\
\text { Narrow palpebral fissures } \\
\text { Loose neck skin } \\
\text { Extremities } \\
\text { Ulnar deviation of hands } \\
\text { Syndactyly } \\
\text { Small mouth } \\
\text { Small jaw } \\
\text { Hammer toes } \\
\text { High palate } \\
\text { Dentition retarded } \\
\text { Ears small, low set } \\
\text { Mental retardation } \\
\text { Hypertonicity } \\
\text { Abductor spasm of hip }\end{array}$ & $\begin{array}{c}\text { M } \\
\mathbf{2} \\
\text { Normal } \\
\text { Long fingers, toes, and forearms } \\
\stackrel{+}{-} \\
+ \\
+ \\
+ \\
+ \\
- \\
+ \\
+ \\
+\end{array}$ & $\begin{array}{c}\text { M } \\
\text { I6 } \\
+ \\
\text { Normal } \\
\text { O } \\
+ \\
\text { Long arms } \\
\text { O } \\
+\end{array}$ & 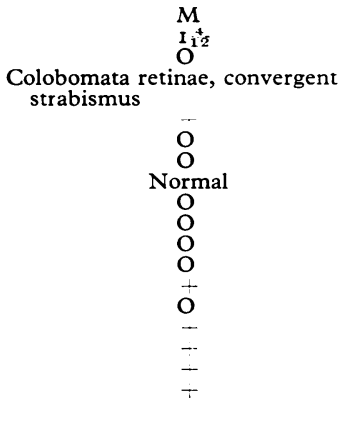 & $\begin{array}{c}\mathbf{F} \\
2_{1}^{10} \\
\text { O } \\
\text { Convergent } \\
\text { strabismus } \\
\text { O } \\
\text { O } \\
\text { O } \\
\text { Normal } \\
\text { O } \\
\text { O } \\
\text { O } \\
\text { O } \\
\text { O } \\
\text { O } \\
\text { O } \\
+ \\
+ \\
+ \\
+ \\
+\end{array}$ \\
\hline
\end{tabular}

TABLE III

CLINICAL SIMILARITIES OF CASES WITH TRISOMY I 8

\begin{tabular}{l|c|c|c|c|c|c}
\hline & $\begin{array}{c}\text { Frøland } \\
\text { et al. (1963) }\end{array}$ & $\begin{array}{c}\text { Gustavson } \\
\text { et al. (1964) }\end{array}$ & $\begin{array}{c}\text { Present } \\
\text { Case }\end{array}$ \\
\hline $\begin{array}{l}\text { Mental retardation } \\
\text { Generalized hypertonicity }\end{array}$ & + & + & - \\
$\begin{array}{l}\text { Low-set malformed ears } \\
\text { Micrognathia } \\
\text { Abductor spasm of hips }\end{array}$ & + & + & + \\
\hline
\end{tabular}

bility that this small metacentric chromosome represents a portion of an extra $\mathrm{X}$ chromosome which has been severely deleted, we are impressed with the clinical similarities between these cases and cases of trisomy 18 syndrome (Table III).

Additional instances of this chromosomal abnormality must be studied before any conclusion can be made.

\section{Summary}

A female infant aged 2 years and Io months is presented who exhibits clinical mental retardation, generalized muscular hypertonicity, and small low-set ears associated with an extra small metacentric chromosome. Three previous cases, all male, of this chromosomal abnormality have been reported. This case establishes evidence that the described chromosomal abnormality is not limited to males. The similarity of clinical findings in these cases and those of trisomy 18 syndrome is presented.

We are indebted to Dr. Bryan Hutt who kindly referred this patient to us, to Dr. Robert D. Mercer, Cleveland Clinic, for his assistance and interest in our cytological studies, and to Mrs. Willard Wright and to Mrs. Marie Leonard for preparations of the photomicrographs.

\section{REFERENCES}

Frøland, A., Holst, G., and Terelev, E. (1963). Multiple anomalies associated with extra small autosome. Cytogenetics, 2, 99.

Gustavson, K. H., Atkins, L., and Patricks, I. (1964). Diverse chromosomal anomalies in two siblings. Acta paediat. (Uppsala), 53, 371 .

Moorhead, P. S., Nowell, P. C., Mellman, W. J., Battips, D. M., and Hungerford, D. A. (1960). Chromosome preparation of leukocytes cultured from human peripheral blood. Exp. Cell Res., 20, 6r3.

Taft, P. D., Dodge, P. R., and Atkins, L. (1965). Mental retardation and multiple congenital anomalies. Amer. F. Dis. Child., 109, 554. 